\title{
Toward a Typology of the Megachurch
}

\author{
J. Gordon Melton
}

In the 1980s, observers of the religious community in America began to take note of a new phenomenon, a movement aimed at the building of large congregations which could serve and actually were attracting crowds of 2,000 or more worshippers on a weekly basis. Leading the trend were congregations that had reportedly reached above 10,000 in weekly attendance. Given the resources that such large congregations could accumulate, they were able to place the best orators in their pulpits, provide professional musicians for worship, utilise the latest developments in audio visual equipment, and offer an array of classes, programmes, and recreational activities not just on Sunday but throughout the week. In their exuberance at discovering the megachurch, religious observers offered a variety of predictions concerning its coming dominance of the religious landscape including its largely pushing aside the smaller congregations of 300 or less members, which had been typical of church life over the previous centuries. In the decades since, urban dwellers have watched large new sanctuaries arise close to freeway exits, their signs welcoming rushhour commuters. The megachurches seemed to be remaking American religion.

Bolstering the claims of the importance of the new megachurches were the changes in religious television and the increasing number of networks devoted entirely to religious programming. Many of the pastors of the largest megachurches were also regularly seen on cable TV, each offering a slightly different presentation, emphasis, and message. By the 1990s, the recognition of the impact of the new wave of megachurches attracted researchers who began long-term observation of the churches, ${ }^{1}$ among the most important being Scott Thumma and his colleagues at the Hartford Institute for Religious Research. Thumma has concentrated on gathering basic data and cataloging the

1 An initial set of studies of the megachurch began to appear in the first decade of the new century and included a recognition of the importance of African American participation in the movement: Barnes (2010); Hey (2013); MacNair (2009); Thumma and Travis (2007); and Tucker-Wongs (2012). 
megachurches which has provided the foundation for our consideration of the phenomena. $^{2}$

\section{Some Historical Background}

In assessing the uniqueness of this seemingly new phenomenon of the megachurch, it is helpful to have some perspective on the overall growth of religion in the United States. Following the American Revolution, with the destruction of the colonial establishments, religion was in a drastically weakened state. The great majority of Americans paid little attention to religion. Ministerial leadership was lacking and in many cases not of the highest quality. Only ten to fifteen percent of the residents were church members. There were no churches at all in the western frontier into which the citizenry was moving. That condition would prompt a reaction by the churches - a great evangelistic push that would last through the nineteenth century. As a result, while the population would grow from 10 million to 75 million, church membership would grow from around 1.5 million to 25 million. Although the church experienced significant growth, it remained the domain of a minority of Americans, with only a third of the population making the minimal effort to affiliate with a church. ${ }^{3}$

Meanwhile, the number of denominations grew significantly, from less than twenty to some 300. Many of these new denominations were regional, with a measurable number established to serve a linguistic and/or racial minority. The growth of so many denominations would in turn prompt the formation of a counter movement that sought to unite the many churches. The ecumenical endeavour experienced some notable success through the twentieth century.

\section{Religion-Population Growth, 1800-1950}

Through the twentieth century, Christianity continued to grow. The denominations began the century counting only a third of the population among their

2 I am in debt to Scott Thumma for his dedicated data gathering, and this paper draws heavily from the data published on the "Database of Megachurches in the U.S." pages of the Hartford Institute for Religious Research website. http://hirr.hartsem.edu/megachurch/database. html.

3 This sketch of the growth of the churches over the nineteenth and twentieth centuries has been assembled from the data presented in Gaustad and Barlow (2001); and Melton et al. (2009). 


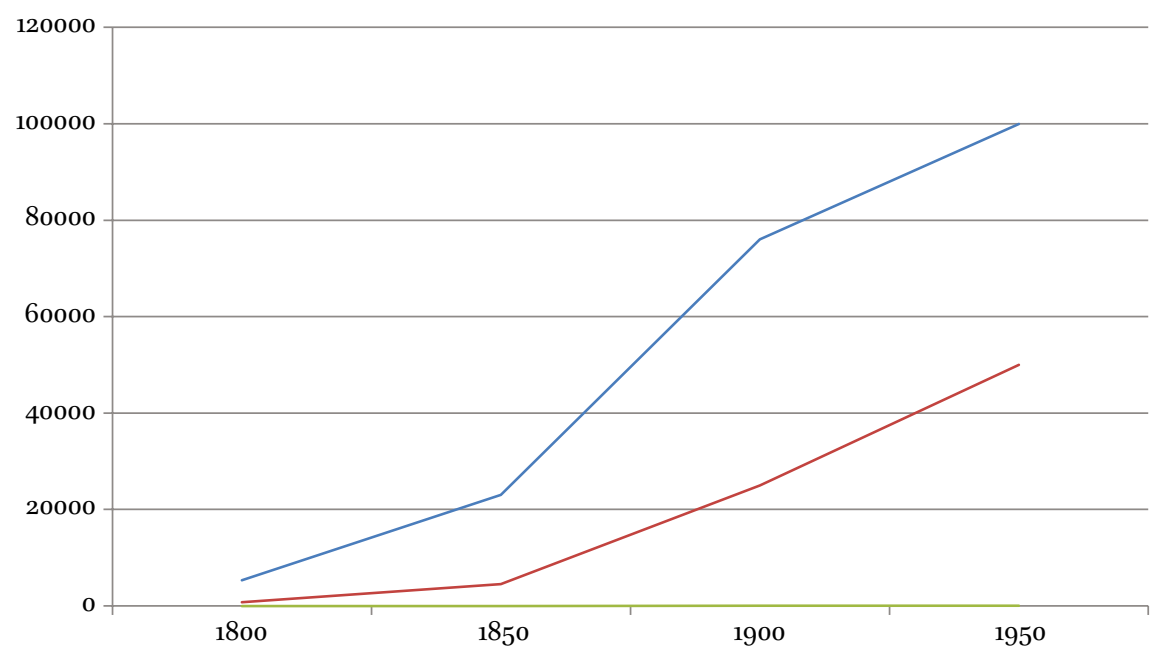

FIGURE 3.1 Population growth (blue line) and church growth (red line) in the USA, 1800-1950.

members but by the end of the 1940s could finally claim half of the public on their rolls and by the end of the century a super majority with more than 70 percent. At the same time, the ecumenical movement experienced significant success in uniting the churches with major splinters of the Protestant churches coming together to form the likes of the Evangelical Lutheran Church in American, The United Methodist Church, the Presbyterian Church (U.S.A.), and the United Church of Christ. At the same time, several dozen churches showed outstanding growth including the Southern Baptists, the Latter-day Saints, and the Missouri-Synod Lutherans. Pentecostalism, founded at the beginning of the century, grew spectacularly with several of its leading denominations The Church of God in Christ, the Assemblies of God, the United Pentecostal Church International - assuming a place among the leading American church bodies, with more than a million members in the United States and a multinational missionary enterprise abroad. African Americans also made their presence felt with the growth of the National Baptists, the African Methodists, and several new Pentecostals bodies like the afore mentioned Church of God in Christ. By 2000, half of the American population were members of just 25 Christian denominations (each with more than a million members). When one added in the next 40 denominations (each with more than 100,000 members) that percentage jumped to nearly 60 percent of the population.

The movement of Americans into the larger denominations did not stop the splintering, however, and dozens of new denominations continued to emerge decade by decade. Many were formed by those who rejected some of the 
modern trends pursued by the larger Protestant denominations, others emerged from new and innovative spiritual impulses, the Pentecostal movement being the most visible. Still others originated from energetic clergy unwilling to stay encased in what they felt to be a limiting denominational structure. Thus, over the twentieth century the number of Christian denominations grew from some 300 to more than a thousand.

While the American religious story often focuses primarily if not exclusively on Protestantism, some acknowledgement needs to be made of Catholicism. Already in the mid-184os, the Roman Catholic Church had become the largest denomination in America, a position it has never relinquished. While remaining politically inactive through much of the next century, it has reasserted its position as a prominent voice on national issues in the decades since World War II. Today Catholic membership is four times larger than its nearest Protestant rival, a status that has a direct bearing on our consideration of megachurches. Recent media attention to the phenomenon, including websites calling attention to the 'largest churches' in America focus entirely on Protestant megachurches. As Thumma has noted, if we were to add the large Catholic parishes to our consideration of megachurches, we would more than triple the numbers, there being some 3,000 Catholic parishes hosting more than 2,00o worshippers each week.

Finally, as we turn our attention back to the presently existing Protestant megachurches, we should note that the erection of large venues for worship is by no means an entirely new phenomenon (Eagle 2015). ${ }^{4}$ Several church sanctuaries that accommodated more than 2,000 worshippers were constructed in the nineteenth century with the idea of creating such structures going back to the sixteenth century, possibly inspired by the likes of St. Peter's Basilica in Rome. The size of such churches was only limited by the ability of preachers to make themselves heard in a day before electrical amplification. Most major cities had at least one such church, the pulpit of each being a target to which talented young preachers could aspire. The contemporary proliferation had been partly facilitated both by the development of amplification systems and the willingness of the present generation to move out of basilica-style church structures into more functional spaces even if void of traditional ecclesiastical trappings. If one covered the signs in front of the buildings and the Christian symbols attached to the front façade, many of the modern megachurches could pass for secular office or warehouse buildings. In fact, many congregations have moved into spaces formerly used for commercial purposes, none

4 See also Stokes (2010). 
more noteworthy than the largest American megachurch, which moved into a former athletic arena.

\section{$4 \quad$ Denominational Backgrounds}

In constructing a typology of megachurches, prominent consideration should be given to their denominational base. This initial focus poses some problems as 'denomination' has become an increasingly contested term in American Protestant circles. Over the last two hundred years each generation has produced movements protesting the division of Protestantism into multiple denominations (each with its more-or-less 'unbiblical' distinguishing name - Lutheran, Baptist, Adventist, Methodist, Episcopal, Mennonite, etc.) and attempted to develop a programme for uniting all the denominations into a single 'Christian' church and/or congregations existing simply as the 'Church of God'. Such movements have repeatedly encountered strong arguments by denominational leaders for maintaining the sectarian truths and practices held dear by each Christian sect, and over time each anti-denominational movement has itself slowly transformed into another new denomination. As each new denomination is formed and incorporated, a distinguishing name would be adopted and trademarked.

Then on a practical level, each new non-denominational congregation settled down to long-term existence, it could not remain merely 'Christian'. It had to adopt an organisational form and a means to make group decisions. As it accumulated property, it had to decide who would hold ownership. It had to relate to governmental structures and regulations and choose how it would acknowledge the near-by presence to other Christian groups. And it had to make theological choices about key practices such as baptism and the Lord's Supper and evolve a theology. It had to choose a name that would distinguish it from all its ecclesiastical neighbours and allow it to incorporate.

In the post-World War II era, a new non-denominational thrust has become evident, with leaders abandoning any privileging of denominational identifications and adopting a name asserting their primary self-image as being simply a 'Christian'. In making that transition, local congregations may, without abandoning their denominational affiliation, adopt a name that makes no reference to their denomination or its particular beliefs and practices. Possibly the most famous instance of such a contemporary congregation is the Saddleback Church , a megachurch in Orange County, California, which is also a congregation of the Southern Baptist Convention. Other congregations refuse any 
organisational alignment with one of the older denominations while largely maintaining the teachings and practices familiar to their founding members. Thus the large Lakewood Church in Houston, while independent of any denomination, operates out of a familiar Charismatic/Pentecostal theological framework similar to that found for example in the Assemblies of God or the Church of the Foursquare Gospel. Other independent megachurches were founded by ministers trained in Baptist seminaries and now lead independent congregations that are Baptist in every way but their name.

In examining the affiliations of the congregations reported in the Hartford database, the new megachurches report affiliations with more than $5^{0}$ different denominations while additional congregations identified with a particular denominational family without designating affiliation with a specific denomination. In fact, contrary to a widespread image, about two thirds of all the 1600+ megachurches are denominationally aligned, with some like First Baptist Church of Dallas and First United Methodist Church of Houston, being old large parishes of America's more established denominations. Others are relatively new congregations that were started in recent decades in fast growing suburbs. Those denominations that continued to grow through the last decades of the twentieth century and the first decade of the new century are especially prominent on the list, with various Pentecostal and Baptist denominations most noticeable.

Of the 89 largest congregations, that is, those reporting an average attendance of 10,000 or more, almost half (39) describe themselves as 'nondenominational. ${ }^{5}$ And it is these largest of the megachurches that have attracted the most attention to the megachurch phenomenon from the media, which often pictures them as offering a new direction away from the older more well-known denominations. The situation is, however, somewhat more complicated.

5 For purposes of this analysis, we have included those reported as affiliation unknown in the non-denominational grouping. We also would note that the confusing term 'non-denominational' has two very different meanings in the literature. Most groups identifying themselves as non-denominational mean that their church is neither affiliated with one of the larger well-known denominations nor identifies with the larger family tradition they represent Baptist, Congregational, Lutheran, Methodist, Presbyterian. Others, including most sociologists and historians of religion think of congregations self-designated as 'non-denominational' as possessing no denominational-like ties whatsoever, which in fact many have. A number of the 'non-denominational' megachurches, for example, are in fact the lead church of one of the newer denominations, albeit one that eschews any reference to the more well-known denominational families. 
Larger churches that report 10,000- or 20,000- or more in weekly attendance immediately raise questions as to how the church accommodates such a number of congregants each Sunday. And immediately one thinks of the standard practice of holding multiple services each Sunday, and in many cases that is what occurs. However, increasingly common is the practice of breaking the congregation up into multiple meeting sites. In fact, many new independent megachurches began with a goal of being a multiple-site community with some like Gateway Church (in Dallas-Fort Worth) developing sanctuaries throughout a large urban complex while others like Antioch Community Church (based in Waco, Texas) developing sites at cities across the United States.

Not unusual among megachurches is Trinity Community Church based in Amarillo, Texas, which describes itself as "one church in many locations". In fact, there are seven locations, three in various sections of Amarillo and its suburbs, and four spread out between Amarillo and Fort Worth (some $35^{\circ}$ miles). Each of the local fellowships carries out a programme, shares basic beliefs and practices, and has its own local leadership. In fact, each Trinity 'site' operates as a new local congregation, each with its own senior pastor, and cooperating together as the Trinity Fellowship of Churches. Thus Trinity Community Church in Amarillo not only emerges as a mega-congregation, but as the lead church of what has become a new 'denomination'.

Similar is Christ the King Community Church based in Burlington, Washington. It describes itself as a single multi-location church. It has ten sites (that is, congregations) in the state of Washington, and additional sites in five other states. Other congregations that at times describe themselves as nondenominational, are in fact congregations of older denominations. For example, The Potter's House, the large congregation led by televangelist Bishop T.D. Jakes, is a congregation affiliated with the Higher Ground Always Abounding Assemblies, an Oneness Pentecostal denomination based in Ohio, Bishop Jakes has been designated as the Assemblies prelate for the southwestern United States. Televangelist Cheflo Dollar not only pastors his large Pentecostal church in Atlanta, but oversees the 'fellowships' of World Changers Church International, with its affiliated congregations meeting across the United States from Los Angeles to Boston. These local fellowships (congregations) are periodically tied together through modern technology with Dollar's sermons being streamed to each location.

As megachurches grow into new denominations they typically found schools to train both lay leaders for the many programmes within the church and future ordained ministers to lead the congregations at the multiple sites. 
The more successful megachurch ministers have joined the ranks of the televangelists, television being one of the most effective tools in contemporary mass evangelism. They will also develop a publishing programme, spearheaded by their own in-house books, cds, and dvds.

Of course, most 'non-denominational' megachurches do not transform into new denominations, many remaining simply large independent congregations. Overwhelming, such non-denominational churches show decided Baptist influence. They tend to be non-creedal, affirm the autonomy of the local church, and practice baptism (by immersion) and the Lord's supper as ordinances (rather than as sacraments). Some will in the future quietly align with one of the 1000+ denominations now existing in the United States with which it discovers an affinity. That being the case, one may begin to classify the nonCatholic megachurches by their affiliation/alignment as:

- Mainline Protestant

- Baptist

- Pentecostal

- Lead church of a new Evangelical/Pentecostal denomination

- Independent unaligned congregation

\section{5}

Numbers

We have already noted that of the 1,6oo+ megachurches less than a hundred have reported attendance over 10,000 or more, of the remainder, the great majority report attendance in the 2,000 to 2,500 range, with the remainder reporting 2,500 to 9,999 in attendance. The cursory examination of the annual reports of the larger denominations indicate that there are many congregations, numbering in the thousands, reporting attendance just below the definitional threshold number of 2,000, attracting from 1,000 to 2,000 for worship weekly. At the same time, there are a variety of significant factors that operate to limit the size of congregations.

Most megachurches have started as small fellowships in areas with high density population, on the fringe of urban complexes. They will begin with rented facilities, often a public school auditorium or hotel meeting rooms. As they grow, they will purchase their own facilities, and may move to multiple sites before finding a relatively permanent site in a facility they have either constructed themselves or one that has been abandoned by a previous congregation. As the congregation grows and its programme diversifies, it needs also increase. It may need multiple buildings, and most importantly, it will need 
additional parking space. As parking increases, so do traffic concerns and the difficulty of a larger number of people making their way to the church. Churches must often move up by moving out of their original neighbourhood. They must seek a new site that has relatively cheap land with ready access to freeways, and proper zoning.

As a congregation grows, at some point it must make a significant financial commitment, which will minimally include raising money for a down payment on new facilities and the maintenance of a mortgage over a number of years. At this point, the pastor's leadership in developing additional streams of income from publishing and/or a broadcast ministry can make a considerable difference in bolstering the confidence of the congregation to move forward. Most megachurch pastors, however, do not author books and do not develop broadcast ministries.

In fact, most megachurches hover around the number 2,000 and for a variety of internal and external reasons will remain there. Not the least of these limiting factors is the implicit commitment to serving the needs of the presently existing congregation. While megachurches feature a large (and largely impersonal) Sunday worship built around a superstar preacher and high quality music, it thrives on more intimate small group meetings during the week. Future expansion for a congregation often means movement to a new location at a significant distance from its present primary site. Such a move upward would often meet opposition from those most negatively impacted by such a move. It becomes easier to grow by developing multiple sites and over a generation transitioning into a new denomination. Megachurches can thus be further classified by numbers, that is, those with attendance around 2,00o (and up to 2,500 ), those attracting 2,500 to 9,999 weekly, and those reporting above 10,000. At each level one will find differences in programme emphases and strategies for future growth.

Location

Megachurches are largely a suburban affair. There are a number of megachurches in small cities and a few in rural areas, though they are limited by the size of their population base and are concentrated among those attracting 2,000 to 2,500 weekly worshippers. There are also a few very large urban megachurches such as Lakewood Church in Houston, West Los Angeles Church of God in Christ, and First Baptist Church in Dallas. Each church has a unique story of how it was able to expand with Lakewood purchasing the sports arena, and both the West Los Angles Cogic and First Baptist Dallas being able to 
locate affordable land close to their earlier locations. Like First Baptist Dallas, a number of the larger urban churches have a long history. Bethel Church in Jacksonville, Florida, for example, is the oldest African American congregation in the city with a history reaching into the Antebellum period, while the Mt. Zion Baptist Church in Nashville, dates to 1866; it was organised immediately after the American Civil War. The Apostolic Church of God in Chicago, a congregation of the Pentecostal Assemblies of the World, was originally founded in 1931.

Typically, however, the largest megachurches have found sites close to freeway exits in the suburbs. Following Houston's Lakewood Church in size are Northpoint Community Church in Alpharetta (suburban Atlanta); LifeChurch in Edmonds (suburban Oklahoma City); Gateway Church in Southlake (suburban Dallas), Willow Creek Community Church in South Barrington (Suburban Chicago), and Fellowship Church in Grapevine (suburban Dallas).

The location of these churches is, of course, a bit more complicated as they are all 'multi-site' churches. Northpoint Community Church ${ }^{6}$ in Alpharetta, for example exists as six congregations scattered throughout the Metro Atlanta area, each with its own programme and leadership, and more than two dozen additional congregations across the United States that have adopted Northpoint's basic theological and operational perspective and are now tied together through North Point Ministries. The 30,00o members who attend LifeChurch ${ }^{7}$ each week are spread out among some 20 congregations in Oklahoma and others in eight additional states. The Gateway Church ${ }^{8}$ has six congregations spread through the northern suburbs of the Dallas Fort Worth Metroplex. Willow Creek Community Church ${ }^{9}$ based in South Barrington now exists as eight congregations scattered throughout Greater Chicago. And the members of Fellowship Church ${ }^{10}$ based in Grapevine attend one of eight congregations, six in Texas and two in Florida.

In reporting on megachurches, Lakewood Church emerges as a somewhat unique congregation, located in a single facility that seats 12,000 people. With three services on Sunday (including one in Spanish) and another on Saturday, its facilities easily accommodate up to 40,00o each week. Other churches reporting weekly attendance in the tens of thousands are working on a relatively new concept of congregational life, a model made possible by modern advances

\footnotetext{
6 http://northpoint.org/.

7 https://www.life.church/.

8 http://gatewaypeople.com/.

9 https://www.willowcreek.org/.

10 https://fellowshipchurch.com/.
} 
in technology, but largely informed by a certain antagonism toward older denominations - a single large church/congregation meeting in many alternate locations often at a significant distance. The idea of "one congregation with multiple locations" is a perfectly appropriate theological assertion, however, the reporting of the attendance of all of the location sites (sometimes termed campuses) as that of a single congregation tends to miscommunicate to the larger community what is happening, especially when described with terminology generally used to refer to traditional single congregations. Thus to its members, Gateway Church is one congregation meeting in eight locations; but to outside observers, it appears as a group of local congregations sharing a common vision, programme, and organisational ties (that is, what has generally been termed a denomination).

Many of these new megachurches have developed from the application of a relatively new church planting philosophy that emerged in the 1980 s out of the perception that some of the larger more-prominent denominations had lost their zeal for church growth, were failing to train their ministers effectively in evangelism, and even in the face of a growing population, had entered a period of decline. Additionally, Evangelical church leaders criticised the larger liberal Protestant denominations with adopting doubtful theological stances, if not outright heresy, and began to project new approaches to church growth that evolved into a new church planting philosophy that had the effect of wooing members from the older denominations. Pioneer exponents of the church planting philosophies trained initial future pastors in tutorial relationships, but as the techniques proved effective, Evangelical seminaries (including seminaries founded by some of the early megachurches) began to integrate new church planting methodologies with their promises of relatively quick success into their curriculum. Meanwhile, the more established seminaries serving the older denominations have been very slow to recognise the competition that the new church planting curriculum represents. ${ }^{11}$

Those churches initially founded and developed using the new church planting techniques have found a home in American suburban settings, but as they have grown, they have been able to start new congregations in the cities (though few have grown into megachurches) and in smaller cities (typically county seats).

11 A sampling of the vast amount of new church-planting manuals would include: Herbert and Herbert Meneses (1995); Ott and Wilson (2011); Payne (2015); Stetzer and Im (2016); and Wagner (2010). 
Thus next to denominational affiliation and size, one can begin to classify megachurches relative to their location, and take notice of at least five types of megachurches:

- Suburban (single location)

- Suburban (multiple locations)

- Urban

- Small city based

- Rural

Even as church planting efforts have been most successful in growing suburbs, they have also shown a regional bias. The majority of megachurches are found in the American Sunbelt with the largest concentration in Texas, southern California, and Florida. One third of all the megachurches in the United States have been established in these three states, with Texas and California being the only states with more than 200 megachurches. It is also the case that the southern states (and their major cities) have been expanding even as the northern states have been declining in population.

\section{$7 \quad$ Theology}

One of the most persistent images associated with the new megachurches is their adoption of a theological perspective generally referred to as the prosperity gospel (Brown nd; Whitehead 2017). A high percentage of the largest of the megachurches (Lakewood, Willow Creek) are led by pastors preaching the prosperity gospel, while a number of the most popular prosperity gospel advocates (Creflo Dollar, Kenneth W. Hagin, Kenneth Copeland, Fred Price) both pastor a megachurch while simultaneously leading a new national denominational network of churches focused on their teachings. While the prosperity gospel is generally associated with Charismatic churches, it is not exclusively so, and counts among its exponents Kirbyjon Caldwell, ${ }^{12}$ the pastor of the $16,000-m e m b e r$ Windsor Village United Methodist Church.

The Prosperity Gospel is a version of the prosperity consciousness movement that emerged in the late nineteenth century. It suggested that those who rose to the top of the corporate world, who became the wealthiest, who reached the top of their chosen field of endeavour, exhibited certain characteristics that set them apart and followed either consciously or unconsciously a set of

12 Cf. Caldwell and Kallstad (2004) and Caldwell with Seal (2000). 
social laws that allowed them to rise above those who merely worked hard. It developed as a secular philosophy passed from the likes of O.S. Marden (1894) and Charles F. Haanal ${ }^{13}$ and reached its epitome in the writings of the likes of Napoleon Hill (1937), radio commentator Earl Nightengale, and Rhonda Byrnes. ${ }^{14}$ It also showed itself capable of merging with different religious perspectives and while originally identified with New Thought, it also found a home among both mainline Protestantism ${ }^{15}$ and Catholicism, and even the Eastern religions.

In the 1970s New Thought found a home among Pentecostals, especially among those previously involved in the 1950s healing movement - Oral Roberts, ${ }^{16}$ A.A. Allen, and Kenneth W. Hagin. Oral Roberts became the first exponent to attract a national audience, while Kenneth Hagin made the prosperity gospel the keystone of his ministry and became the first to build a national following and organisation with teachings on prosperity a foundational teaching. From his base in Tulsa, Oklahoma, he successively built a megachurch, a school, and a national network of congregations pastored by people trained in the school. Many of the current prosperity gospel exponents were at one time his students, and all matured theologically reading his material. ${ }^{17}$

To some extent, the association of the megachurch with the prosperity gospel has a basis in fact. A number of the more well-known pastors of the largest megachurches are advocates and the prosperity theme permeates their books and television shows, and is integrated into the life of the congregations founded by their hundreds of students. The prosperity gospel resonates with the entrepreneurial spirit that is found in the pastors willing to go out and found churches from scratch in unfamiliar settings and keeps them motivated through the years of initial growth. It also resonates with lay members who are

13 Haanal, like his mentor O.S. Marden, published a number of books expanding upon his approach to success and prosperity, most notably his 1912 classic, The Master Key System. He in turn inspire Napoleon Hill.

14 Rhonda Burns is the most recent author on prosperity consciousness as the author of the best-selling text The Secret (2006).

15 Norman Vincent Peale brought prosperity consciousness into mainline Protestantism in the 1950s with his best-selling The Power of Positive Thinking (1932).

16 Oral Roberts introduced prosperity consciousness into Pentecostal circles as early as 1956 with is pioneering text, God's formula for Success and Prosperity (1956).

17 Since the elder Hagin's death, televangelist Kenneth Copeland has emerged as an important force in promoting the prosperity gospel through his Believer's Voice of Victory television network and his annual conferences that regularly feature the major prosperity advocates including Jerry Savaille, Jesse Duplantis, Keith Butler, Creflo Dollar, Kenneth W. Hagin, and Rick Renner. 
struggling upward in a career in the business world where prosperity consciousness sustains them as they work their way toward success.

At the same time, while the prosperity gospel is found in a number of the more prominent megachurches, it is by no means the majority opinion. One can find an equal number of megachurches based in twentieth century Evangelicalism, as well as the majority of megachurches that have found a home in the major denominational life and thought.

Thus as a final tool in classifying megachurches, one can ask about the church's theological tradition. The majority appear to operate out of a Calvinist Baptist perspective with the next largest groups from a traditional Pentecostal Charismatic background. It is among those of a Charismatic background that the prosperity gospel has most prospered.

\section{$8 \quad$ Conclusion}

The new megachurches are among the more important phenomena to appear as the twenty-first century has begun. While acknowledging its importance, we should not over estimate its importance. Among the hundreds of thousands of congregations now found across the United States, there are less than 2,000 megachurches. They have an extraordinary impact due to their presence on religious television and their being the home to many of the most talented orators in the world of preaching. However, they are not replacing or pushing aside the smaller congregations in which the overwhelming majority of Christians still find their church home.

As a whole, they find their role in continuity with past Christian history in which there have always been larger congregations housed larger buildings among the many average and smaller congregations. In the two hundred-plus years of the American church, there has been a steady increase in the number of new denominations (the number tied to the growth in population and the trend toward urbanisation) from the original 15 that formed immediately after the Revolution to the 1,100-plus in the present. While the majority of megachurches still represent the largest congregations of the older congregations to which the most talented and successful ministers can aspire, some of the megachurches have become the seedbed of still more new denominations emerging largely in the growing suburbs surrounding the country's urban complexes.

In looking at any given megachurch we can get some handle on its life (and to some extent its future) by inquiring into four factors - its denominational 
TABLE 3.1 Denominations, size and theological perspective

\begin{tabular}{llll}
\hline Denomination & Size & Location & Theological Perspective \\
\hline Protestant & $2,000-2,500$ & Urban & Reformed/Baptist \\
Evangelical & $2,500-9,999$ & Suburban & Pentecostal/Charismatic \\
Pentecostal & $10,000+$ & Small City & mainstream Protestant \\
Unaligned & & Rural & Other \\
& & & \\
\hline
\end{tabular}

affiliation, its size, its location relative to the nearest urban complex, and its theological perspective.

\section{References}

Barnes, S.L. 2010. Black Megachurch Culture: Models for Education and Empowerment. New York: Peter Lang Inc./International Academic Publishers.

Brown, D. nd. "How Megachurches Blurred the Line between Religion and Riches." Posted at: https://people.howstuffworks.com/do-megachurches-preach-that -prayer-will-make-rich.htm.

Burns, R. 2006. The Secret. New York: Atria Books/Beyond Words.

Caldwell, K. and Kallstad, W. 2004. Entrepreneurial Faith: Launching Bold Initiatives to Expand God's Kingdom. WaterBrook Press.

Caldwell, K. with Seal, M. 200o. The Gospel of Good Success: A Road Map to Spiritual, Emotional and Financial Wholeness. New York: Touchstone.

Eagle, D.E. 2015. "Historicizing the Megachurch." Journal of Social History. 48, 3 (April), 589-604.

Gaustad E.S. and Barlow, P.L. 2001. New Historical Atlas of Religion in America. New York: Oxford University Press, 3rd edition.

Hey, S. 2013. Megachurches: Origins, Ministry, and Prospects. Eugene, OR:Wipf \& Stock. Herbert P.G. and Herbert Meneses, E. 1995. Incarnational Ministry: Planting Churches in Band, Tribal, Peasant, and Urban Societies. Grand Rapids, MI: Baker Academic.

Hill, N. 1937. Think and Grow Rich. The Ralson Society.

MacNair, W.E. 2009. Unraveling the Mega-Church: True Faith or False Promises? Santa Barbara, CA: Praeger.

Marden, O.S. 1911 [1894] Pushing to the Front. Petersburg, NY: The Success Company.

Melton, J.G., Grammich, C., Hadaway, Houseal, R., Jones, D.E. and Krindatch, A. 2007.Nelson's Handbook of Denominations. Nashville, TN: Thomas Nelson. 
Melton, J.G. James, BeverleyConstance, Jones and Pamela S. , Nadell20og. Melton's Encyclopedia of American Religion. Detroit: Gale/Cengate Learning, 8th edition.

Ott, C. and Wilson, G. 2011. Global Church Planting: Biblical Principles and Best Practices for Multiplication. Grand Rapids, MI: Baker Academic.

Payne, J.D. 2015. Apostolic Church Planting: Birthing New Churches from New Believers. Downers Grove, IL: IVP Books.

Roberts, O. 1956. God's formula for Success and Prosperity. Tulsa, OK: the Author.

Stetzer, E. and Im, D. 2016. Planting Missional Churches: Your Guide to Starting Churches that Multiply. Nashville, TN: B\&H Academic.

Stokes, D. 2010. Apparent Danger: The Pastor of America's First Megachurch and the Texas Murder Trial of the Decade in the 1920s. Minneapolis, MN: Bascom Hill Books.

Teel, Jr., R.A. 2008. Against the Grain: The American Mega Church and its Culture of Control. Chatsworth, CA: NarroWay Press.

Thumma, S. and Travis, D. 2007. Beyond Megachurch Myths: What We Can Learn from America's Largest Churches. San Francisco: Jossey-Bass.

Tucker-Wongs, T.N. 2012. The Black Megachurch: Theology, Gender, and the Politics of Public Engagement. Waco, TX: Baylor University Press.

Wagner, C.P. 2010. Church Planting for a Greater Harvest: A Comprehensive Guide. Eugene, OR: Wipf \& Stock Publishing.

Whitehead, B. 2017. "An Unholy Marriage: MegaChurches and the Prosperity Gospel." Christianity Now (May 1). 